\title{
Changing social metabolism and environmental conflicts in India and South America
}

\author{
Joan Martinez-Alier ${ }^{1}$ \\ Federico Demaria \\ Leah Temper \\ Mariana Walter \\ Autonomous University of Barcelona, Catalonia, Spain
}

\begin{abstract}
Firstly, we present some environmental conflicts gathered in 2016 in the EJAtlas, selecting a few that have implied deaths of environmental defenders around the world including India and South America. Such conflicts arise from changing trends in the social metabolism. Secondly, we compare India and South America in terms of internal metabolism and international trade. We show that South America and India are at different moments in the race (concomitant with increased GDP per person) for the use of materials. South America reached a level of extraction of over 10 tons per person/year of all materials. It is unlikely that this will increase much. Maintaining this level already means environmental pressures. A substantial part goes for exports, much larger than the imports. In contrast, India was until recently at a level not much above 5 tons of material use per capita/year. If the Indian economy grows, as it is likely to do, the social metabolism will increase in volume more or less in proportion to economic growth. The use of biomass will increase much less than that of building materials and fossil fuels. This follows the regular patterns of economic growth. Internally, the Indian economy exploits some states as providers of raw materials in a pattern of ecological internal colonialism but internationally (in terms of material flows), it is not subject to 'ecologically unequal exchange', contrary to South America. Finally, we use some statistics from the EJAtlas comparing participation of indigenous and traditional populations and rates of 'success' in local struggles for environmental justice in both subcontinents, to see whether the global movement for environmental justice can help to slow down the destruction of the environment and local livelihoods and cultures.
\end{abstract}

Key words: EJAtlas, material flows, economic growth, ecological distribution conflicts, environmental defenders, ecologically unequal trade, internal colonialism

\section{Résumé}

Tout d'abord, nous présentons quelques conflits environnementaux réunis en 2016 dans les EJAtlas, en sélectionnant quelques-uns qui ont impliqué la mort de défenseurs de l'environnement dans le monde entier, y compris l'Inde et l'Amérique du Sud. Ces conflits découlent de l'évolution des tendances du métabolisme social. Deuxièmement, nous comparons l'Inde et l'Amérique du Sud en ce qui concerne le métabolisme interne et le commerce international. Nous montrons que l'Amérique du Sud et l'Inde se situent à des moments différents dans l'utilisation des matériaux (concomitante à l'augmentation du PIB par personne). L'Amérique du Sud a atteint un niveau d'extraction de plus de 10 tonnes par personne / an pour tous les matériaux. Il est peu probable que cela augmentera beaucoup. Maintenir ce niveau signifie déjà beaucoup de pression sur l'environnement. Les exportations sont beaucoup plus importantes que les importations. En revanche, l'Inde était, jusqu'à une date récente, à un niveau qui ne dépassait pas 5 tonnes d'utilisation matérielle par habitant / an. Si l'économie indienne se développe, comme il est susceptible de le faire, le métabolisme social augmentera en volume plus ou moins proportionnellement à la croissance économique. L'utilisation de la biomasse augmentera beaucoup moins que celle des matériaux de construction et des combustibles fossiles.

${ }^{1}$ Dr. Joan Martinez-Alier, Emeritus Professor, ICTA, Universitat Autonoma de Barcelona, Catalonia, Spain. Email: joanmartinezalier "at" gmail.com. Dr. Federico Demaria Dr. Leah Temper and Dr. Mariana Walter, Research Fellows, ITCA-UAB. Acknowledgements: EJOLT FP7 proiect (2011-15) and EnvJustice ( Advanced Grant from the European Research Council awarded to Martinez-Alier, 2016-21). This is an updated and much revised version of Martinez-Alier et.al. 2016. Social metabolism and environmental conflicts - a comparison between India and Latin America. In Dale, G. et al. (eds.) 2016 Green growth. London: Zed Books. We are grateful to Grettel Navas and Brototi Roy for help. This is the ninth article in Alf Hornborg and Joan Martinez-Alier (eds.) 2016. "Ecologically unequal exchange and ecological debt", Special Section of the Journal of Political Ecology 23: 328-491. 
Cela suit les modèles réguliers de croissance économique. En interne, l'économie indienne exploite certains États comme fournisseurs de matières premières dans un modèle de colonialisme écologique interne. Mais à l'échelle internationale (en termes de flux de matières), elle n'est pas soumise à des «échanges écologiques inégaux», contrairement à l'Amérique du Sud. Enfin, nous utilisons des statistiques de l'EJAtlas comparant la participation des populations autochtones et traditionnelles et les taux de «succès» dans les luttes locales pour la justice environnementale dans les deux sous-continents pour voir si le mouvement mondial pour la justice environnementale peut aider à ralentir la destruction de l'environnement, Et les moyens de subsistance et les cultures locales.

Mots clés: EJAtlas, flux de matières, croissance économique, conflits de distribution écologique, défenseurs de l'environnement, commerce écologiquement inégal, colonialisme interne

\section{Resumen}

En primer lugar presentamos algunos conflictos ambientales incorporados en 2016 al EJAtlas, seleccionando unos pocos que incluyen la muerte de defensores ambientales, en todo el mundo, incluidas la India y Sudamérica. Esos conflictos nacen de las cambiantes tendencias del metabolismo social, En segundo lugar, comparamos la India y Sudamérica con respecto a su metabolismo interno y también al comercio exterior. Sudámerica y la India están en momentos distintos en la carrera del uso de materiales por persona concomitante con el crecimiento del PIB. Sudamérica alcanzó un nivel de extracción de 10 toneladas por persona y año de todos los materiales, y es poco probable que eso aumente mucho más. Mantener este nivel ya implica mucha presión sobre el ambiente. En contraste, la India ha estado hasta hace poco tiempo a un nivel inferior a 5 toneladas por persona y año. Si la economía de la India crece, como es muy probable que ocurra, el metabolismo social crecerá más o menos al mismo ritmo que la economía. El uso de biomasa crecerá menos que el de materiales de construcción y los combustibles fósiles. Eso sigue las pautas generales del crecimiento económico. Internamente, la India explota algunos estados como proveedores de materias primas en una pauta de colonialismo ecológico interno pero en internacionalmente la India no padece (en términos de flujos de materiales) un 'comercio ecológicamente desigual', al contrario de Sudamérica. Finalmente, usamos algunas estadísticas del EJAtlas comparando en ambos subcontinentes la participación de la población indígena y tradicional y los porcentajes de 'éxito' en conflictos locales por la justicia ambiental para ver si el movimiento global de justicia ambiental puede ayudar a frenar la destrucción del ambiente natural y de los medios de subsistencia y las culturas locales.

Palabras clave: EJAtlas, flujos de materiales, crecimiento económico, conflictos ecológico-distributivos, defensores ambientales, comercio ecológicamente desigual, colonialismo interno.

\section{Introduction: the economy is not circular, it is entropic}

Why are there so many ecological distribution conflicts around the world? Of all the materials entering the economy (fossil fuels, building materials, metal ores, biomass) only about 6\% are recycled (Haas et al., 2015). All societal material flows (globally) were traced by Haas et al.'s recent research from extraction to disposal, and presented for main material groups for 2005. While globally, roughly 4 gigatonnes per year (Gt/yr) of waste materials are recycled, this flow is of moderate size compared to $62 \mathrm{Gt} / \mathrm{yr}$ of processed materials and outputs of $41 \mathrm{Gt} / \mathrm{yr}$. (1Gt = 1000 million tons). The $62 \mathrm{Gt} /$ year of 2005 meant an average per person of 9.4 t/yr. According to Haas et al., the low degree of circularity has two main reasons. First, $44 \%$ of processed materials were used in 2005 to provide energy and were thus not available for recycling. Second, socioeconomic stocks were still growing at a high rate with net additions to stocks (in 2005) of $17 \mathrm{Gt} / \mathrm{yr}$.

The global industrial economy uses exhaustible resources like the fossil fuels. It burns them for energy. The energy dissipates. This also produces gaseous residues like $\mathrm{CO}_{2}$ in excessive quantities (hence, the increased greenhouse effect). The economy also exhausts renewable resources, like fisheries, undermining the 'funds': the fertility of the soil, biodiversity, and the natural water cycle (that becomes the 'hydro-social cycle' when dams interrupt water courses). The industrial economy has a voracious appetite for fresh supplies; it goes to the commodity extraction frontiers to get new resources, in greater and greater quantities. And it deposits the waste anywhere it can (the atmosphere, the oceans, the rivers and soils...). It does not matter what the European Commission or the Chinese Communist Party say about the impending arrival of the circular economy. Good luck to them. Even the European Greens promote a circular economy: "We Greens are 
committed to using our political influence at local, national and EU level to trigger the switch to a circular economy". ${ }^{2}$ These are failed performative utterances.

On the contrary, even a non-growing industrial economy would need to obtain fresh materials and energy, because energy is dissipated and materials are recycled to only a small extent. Because of this, there are more are more ecological distribution conflicts, such as those that we gather in the EJAtlas (Temper et al., 2015). Ecological distribution conflicts thus take place at several scales. At global and national levels there are complaints about climate change and the acidification of the oceans, the wholesale disappearance of biodiversity, or the systematic infringements to the Basel Treaty against waste exports and other manifestations of ecologically unequal trade. At local scales, communities may protest against bauxite or coal mining, biopiracy, waste dumping, palm oil plantations, or the destruction of mangrove forests. In this article we trace the origins of ecological distribution conflicts to changes in the societal flows of energy and materials (including waste) and make comparisons between South America and India. The industrial economy is based on the use of fossil fuels. The materials used can be recycled, but only to some extent. When the economy grows, inputs keep increasing: fossil fuels, biomass (food, feedstuffs, wood, pulp, paper, agrofuels), building materials, and mineral ores.

\section{The everyday killing of environmental defenders}

We start with short descriptions of six recent environmental conflicts cases reported in the EJAtlas (www.ejatlas.org) where supporting evidence is available. All belong in different degrees to the category of "environmentalism of the poor and the indigenous" (Guha and Martinez-Alier, 1997, 1999; Martinez-Alier 2002), and featuring conflicts over different commodities (gold and copper; coal; ilmenite for titanium; hydroelectricity). But they have one trait in common - the death of environmental defenders in the course of 2016. Two are from India, two from Latin America, one from the Philippines, one from South Africa. In 2015, Global Witness counted 185 environmental defenders killed around the world, but admitting to underreporting. ${ }^{3}$ So, this small sample of six cases (involving about 15 killings) is only a trailer for the forthcoming toll to be published by Global Witness for the year 2016. According to Global Witness, relative to population, the Philippines and Honduras are at present two of the top countries for killings of environmental defenders. India is not, but there is probably under-reporting in the central states of India where there is much political violence. Brazil, Colombia, Mexico and Peru are among the countries in the world where killing of environmental defenders happens most often.

In some of our cases there is an inkling of a hopeful alliance between actors from two different varieties of environmentalism: conservationism and the environmentalism of the poor (in Arunachal Pradesh and in Podoland in South Africa). We wish that the IUCN would become involved in a global information campaign in favor of environmental defenders. In some cases the protagonists are transnational companies (including two from China, one from the USA, one from Australia) and in other cases they are national companies (private or public, like the National Coal Company of India). Some of those murdered are women (including Teresita Navacilla in the Philippines and Berta Cáceres in Honduras), and almost all belong to indigenous peoples who live at commodity extraction frontiers (Moore 2000). In almost all cases there are local NGOs (or rather EJOs, environmental justice organizations) helping to make public the events, even when they are not directly involved in them. The conflicts are about extraction or also about transport (e.g. Las Bambas in Apurímac, Peru). All the materials or electricity extracted are destined for export (or sent to other states, as in India), fitting into the 'extractivist' critique of Acosta (2013), Gudynas (2009) and Svampa (2015) in South America. Electricity would go largely to the mining industry (as in Honduras). Sometimes the protagonists of the conflicts deploy non-monetary values such as sacredness of parts of their environment, and calling for respect for indigenous territorial rights; sometimes they accept monetary compensation for damages. This could lead us to a more substantial analysis of 'valuation languages' (Martinez-Alier 2002).

\footnotetext{
${ }^{2}$ https://europeangreens.eu/utrecht2016/circular-economy

3 https://www.globalwitness.org/en/reports/dangerous-ground
} 
The six cases ${ }^{4}$

(1) The gold and copper open pit King-King project in Pantukan, Southern Mindanao, Philippines threatens the rich biodiversity of the region. The King-King mining project will be the second largest copper and gold operation in the Philippines, and owned by the Nationwide Development Corporation (NADECOR) and St. Augustine Gold and Copper Limited (SAGCL). They plan an open pit mine of 1,656 ha in the Pantukan region. The environmental group Panalipdan-SMR warned that the proposed King-King mine would affect twelve 'vulnerable or critically endangered' species of the 253 native or endemic plant species present in the area, as defined by the International Union for Conservation of Nature (IUCN) Red List and the Philippine National Red List. These include six species endemic to Mindanao, and a total of 17 mammals and 10 reptiles. The region is also home to the Philippine eagle Pithecophaga jefferyi, which will be further endangered as a result of these mining projects. Panalipdan-SMR also note that several species of sea turtles, dolphins, whales, and seabirds live along the coast. The sea cow (Dugong dugon) and all species of sea turtle (Chelonioidea) found in the region are listed as endangered. Human rights are also threatened. Teresita Navacilla was one four protesters killed in January 2016. Three days after being shot, she died in a hospital in Tagum City. She had spoken out against the King-King mining project and she was a member of the Save Pantukan Movement, a network of indigenous peoples in Compostela Valley province (some of them, small-scale miners) fighting for the right to their ancestral lands, advocating for more stringent environmental protection, and opposing large-scale open pit mining by foreign corporations. On 27 January 2016, two unidentified armed men attacked her. One entered her store in Purok Bardown and shot her twice, before both men drove away on a motorcycle. The attack was reportedly carried out by soldiers from the 46th Infantry Battalion, which had been assigned to secure the King-King mining project. Inhabitants of the Compostela Valley report that the soldiers have arrested and assaulted Mansaka indigenous people, and other civilians have been opposing the mine. The commander of the 46th Infantry Battalion denied any involvement of his soldiers. Front Line Defenders condemned the killing of Teresita Navacilla while Hanimay Suazo, secretary general of human rights group Karapatan, said that "she is the 54th victim of extrajudicial killings in Southern Mindanao since 2010 and the fourth victim here in just one month". ${ }^{5}$ He claimed the Army was responsible, following arrests of innocent civilians and branding them as members of the New People's Army (armed wing of the Communist Party). They target small scale miners, farmers and lumads of the Mansaka tribe who are opposing the operations of the two mine owners.

(2) The farmers of Badkagaon in Jharkhand, India, have been struggling against the National Thermal Power Corporation (NTPC) since 2004, which was when it was allotted coal mining concessions. On October 1, 2016, in the early morning hours, police fired 60 rounds of bullets at villagers on a peaceful sit-in protesting against unjust land acquisition in Hazaribagh district. They killed five, and injured at least 40 more. Seven years after it started acquiring land for mining, the NTPC has only been able to acquire 4,043 acres (1,636 ha), about half of what it needs (8,055 acres/3,260 ha, including forest and government-owned land). There are 8,745 families affected by the seizure of land, but only 2,614 have accepted compensation, and moved. The rest are still protesting against illegal methods of land acquisition and inadequate compensation. The Karnapura Bachao Sangarsh Samiti association has been active since 2004 in protecting farmland. It has carried out a number of protests, marches and demonstrations, including two Koyla Satyagraha, in which the local people mined coal themselves by hand, and submitted the money they earned to the national treasury, claiming, "If the government wants the coal beneath out land, we will give it to them, but we won't part with our fertile land." In 2015, a consortium of two companies, Thriveni Earthmovers and Sainik Mining, won a tender to begin mining by the end of 2016. Amidst many protests, and with heavy security, mining begun on May 17, 2016. This is not the first time Thriveni has been involved in controversial operations; it was also accused of illegal mining in Odisha, by the Shah Commission of

\footnotetext{
${ }^{4}$ Much of the material from the cases comes from the EJAtlas, some in translation, and the references to reports and journalism cited in footnotes.

${ }^{5}$ https://www.frontlinedefenders.org/en/case/case-history-teresita-navacilla
} 
Inquiry in 2014. ${ }^{6}$ Once mining began, politicians from opposition parties supported the villagers to resume the struggle for their rights to land and livelihood. On August 14, there was another altercation when 200 villagers prevented NTPC contractors from building a resettlement colony. The villagers threw stones, and the police responded with tear gas and 22 rounds of ammunition, injuring six people. They included a journalist, and they were later arrested when they reached a civil hospital in Hazaribagh for treatment. On September 15, around a thousand villagers started a sit-in protest near a mining site in Chiru Barwadih village, and it was this that provoked the police brutality and deaths on October 1, 2016. Villagers who were protesting rights to land and livelihoods have been beaten and harassed many times before. A First Information Report (FIR, a written document prepared by police) is an effective tool for intimidation and police threats. One has been issued against '500 unnamed persons' for blocking mining operations and allegedly attacking the police. This effectively means that the police can arrest anyone from the village, as there are no names in the FIR. This forced hundreds of families to flee their homes after police and paramilitary forces carried out a door-to-door search of houses in the villages of Chapakala, Chipakhurd, Sonbarsa, Churchur, Arahar and Nagri. Due to the nameless FIR, no search warrant was needed. The conclusion is that as in other cases of environmental justice movements in India, there has been a pattern of resistance, brutality and violence, human rights violations, and underpinned by asymmetric power structures. Illegal methods and intimidation have been used to coerce people into giving up their fertile land on unfavorable terms. The government claims that the current agitation is mainly due to two political figures - Yogendra Saw, a former MLA (Member of Legislative Assembly) for Barkagaon in Hazaribagh district, and to Nirmala Devi, the current member. And yet, resistance actually began in 2004. The couple has been accused of "instigating the mob to resort to violence."

(3) The Australian company, Mineral Commodities Ltd. (MRC), through its subsidiary Transworld Energy and Minerals (TEM) and local partner Xolco, has proposed for some time to mine ilmenite, rutile, zircon from sand dunes at Xolobeni on the Pondoland Coast of South Africa. Approximately $40 \mathrm{~km}$ long and up to $3 \mathrm{~km}$ wide, the area falls within the Pondoland Centre of Endemism (PCE), a globally recognised botanical hotspot. Mining first strips all vegetation, then uses giant dredge ponds to extract minerals for processing at smelters elsewhere. Large quantities of fresh water, and electricity sourced from coal fired power stations in South Africa would be needed. If mining proceeds, local people would need to leave the land that supports their agrarian livelihoods, traditions and spiritual and customary land-use practices. Mining will degrade the environment and undermine the wellbeing of local communities due to open-cast mining of titanium ores and other minerals from sand dunes south of Port Edward in the Amadiba traditional area. Should it go ahead, the mining would displace more than 200 households. The future of the open cast operation to mine ilmenite for titanium, rutile and zircon on pristine sand dunes, hangs in the balance. In July 2016 the Australian company sold its shares and quit, after the tragic events of March 2016 when opponents of mining in the Xolobeni area feared for their lives after the chairman of the Amadiba Crisis Committee, Sikhosiphi Bazooka Rhadebe, was assassinated on 22 March. Rhadebe was shot eight times outside his house in Lurholweni township at Mbizana. The Crisis Committee represents community members who have been fighting the mining development for the last 10 years. They argue that tourism should be the mainstay of the economy in this remarkably biodiverse 'Wild Coast'. Committee member Nonhle Mbuthuma told GroundUp that just before his death Rhadebe had phoned her to check on her safety and that of another committee member, Mzamo Dlamini. He had spoken of a hit list on which his was the first name, and hers and Dlamini's the second and third. An hour and a half later, he was dead. Two men had knocked at the door saying they were police officers. "After one year of threats and attacks, we have been waiting for something like this to happen", said Mbuthuma in a statement issued after the assassination. ${ }^{7}$ The crisis committee had said the Amadiba coastal community "will not be intimidated into submission. Imining ayiphumeleli! (mining will not succeed)". The Amadiba Crisis Committee accuses MRC and its local partners and

\footnotetext{
${ }^{6}$ http://mines.nic.in/ViewData/index?mid=1333

7 http://www.ejolt.org/2016/04/south-africa-mining-takes-violent-turn
} 
allies of using violence to intimidate the community into accepting the mine. According to some interpretations, apart from the search for ilmenite for titanium in other coastal areas of South Africa and elsewhere, there are links to developments in South African current politics. The context of Radhebe's murder is a scramble for self-enrichment by chiefs, not confined to the Wild Coast. A raft of laws since the advent of democracy has progressively given power over land and people to traditional leaders. A delay of almost ten years after the first democratic elections of 1994 in defining the roles and powers of chiefs has created a vacuum, and some ambitious chiefs are seeking despotic sovereignty, reminiscent of their roles in the apartheid era Bantustans. With the discovery of minerals on land that was considered of little value under apartheid, and to which black South Africans were consigned by laws like the Group Areas Act, things have gone from bad to worse for ordinary citizens. Many chiefs are scrambling to push themselves to the forefront of companies for selfenrichment from mining deals. This is the case in Xolobeni.

(4) Because of her opposition to the Agua Zarca dam in Honduras, on 3 March 2016, Berta Cáceres, a local social and environmental leader, was killed. ${ }^{8}$ Hydroelectric projects were previously prohibited by law in conservation areas. But on 24 August 2009 a General Law for Waters was passed, under the de facto government following a coup d'etat. It gave concessions to water companies, and also approved Decree 233 that permits dams once again. The territory of the Lenca people is one of those most affected because 17 dams are planned there, and several of them are subsidized by CDM money ('clean development mechanism', giving carbon credits). Between 2010-2013, the Agua Zarca hydroelectric project was approved in the northwest of Honduras in the departments of Santa Bárbara and Intibucá, close to the Wild Life Reserve of Montaña Verde. This is a small project of 21.3 MW capacity, through a concession for 20 years on the Gualcarque River, which is sacred to the Lenca indigenous peoples and part of Maya culture. For them, this river is the space where spirits of indigenous girls live. It is an inheritance from the Cacique Lempira, who fought against the Spaniards for these territories at the time of colonization. In 2012 the BCIE (Banco Interamericano de Integración Económica) loaned US\$24.4m to Desarrollos Energéticos S.A. (DESA) of Honduras, to build the hydroelectric project. DESA subcontracted two companies to build the turbines: Sinohydro, a large Chinese company which was promptly accused by local communities of land grabbing without any previous consultation, and the German company Voith Hydro Holding GmbH \& Co. One year later Sinohydro left, because of local unrest. Since 2011, government authorities and DESA had entered the territory to convince the local people of the benefits of the hydroelectric project, without success. Nevertheless the work started, and the Lenca peopled alleged that Convention 169 of ILO (ratified by Honduras in 1995) had been violated because there was no process of previous and informed consultation. On the contrary, those local leaders who are openly against the project are threatened, brought to court, or killed (as was Tomás García in 2013 and Berta Cáceres in 2016). Both were members of the main resistance group, the Consejo Cívico de Organizaciones Populares e Indígenas de Honduras (COPINH). Since 2013 the Lenca people were not allowed to access the river waters and on $1^{\text {st }}$ April 2013 a blockade started on the road that leads to the dam. This is continuing as they demand all heavy equipment from the company be withdrawn. The DESA's official page claims that construction works have advanced only 15 per cent. Criminalization of the leaders of the dam opponents continues, as do murder threats. The area is militarized by military police. The murder of Berta Cáceres followed her receipt of the prestigious Goldmen Prize in 2015. She was shot dead in her home after receiving dozens of death threats related to her opposition to the Agua Zarca dam on the Gualcarque River, which she said was being constructed without the consent of the local population. She was the most high-profile victim in a string of killings that still continues; according to Global Witness, more than 100 environmental activists were murdered in Honduras between 2010 and 2015. On March 15, 2016, Nelson García, also an activist of COPINH, was shot and killed when he helped a group of poor families resist a land grab in the small town of Rio Lindo. This murder was not directly related to the conflict around the Agua Zarca dam, but it is part of a pattern on intimidation. The Ombudsman office for the

${ }^{8}$ http://www.ejolt.org/2016/03/international-condemnation-murder-indigenous-leader-bertha-caceres-honduras 
International Finance Corporation (IFC) of the World Bank explained in a report of December 2013 that IMF subsidiaries had pulled out of project loans. ${ }^{9}$ The FMO, the Dutch development financier, suspended activities in Honduras. Finnfund, the second European financier involved in Agua Zarca, suspended its support as well.

(5) Another hydroelectricity project, the Nyamjang Chhu dam in Tawang, Arunachal Pradesh, India, was also in the news in 2016. Public protests against the construction of dams in the Tawang district in North East India have been going on for some years. ${ }^{10}$ There are ambitious targets to generate 50,000 MW of electricity through hydroelectricity in Arunachal Pradesh. Little of this has been yet built. On 2 May 2016 (as fully reported in The Wire, 3 May $^{11}$ ) things took a deadly turn; during a demonstration calling for the release of arrested anti-hydropower movement leader Lama Lobsang Gytaso in Tawang, two people were killed on the spot by indiscriminate and unannounced police firing. A statement of the Save Mon Region Federation (SMRF), the organization spearheading the protests, identified four other victims who succumbed to their injuries later in the day, including one woman. Tawang is the last Indian district bordering China, historically part of Tibet. The 1914 Simla Accord defined the McMahon line as the new boundary between British India and Tibet. By this treaty Tibet relinquished several hundred square miles of its territory, including Tawang, to the British, but this was not recognized by China. This $2,085 \mathrm{~km}^{2}$ district, reaching over 4,000m altitude and very mountainous, was invaded by the Chinese army in 1962 and only relinquished after a ceasefire. Tawang is home to the Monpa people, and has the well-preserved Tawang Monastery; it is a seat of Tibetan Buddhism. Since 2011 there have been public protests against the state government's decision to dam rivers, driven by environmental and religious concerns. Reportedly, thirteen of more than 150 planned hydroelectric projects are in Tawang. To stall this spree of dam construction, people from the Monpa community joined hands with local Buddhist monks in 2011 to form the Save Mon Region Federation (SMRF). On April 7th 2016 the National Green Tribunal suspended environmental clearance for the 780 MW Nyamjang Chhu project in response to a successful appeal filed by the Save Mon Region Federation. The Tribunal asked for a fresh impact assessment studies, public hearings, and reports by the Expert Appraisal Committee on River Valley \& Hydroelectric projects and the Ministry of Environment, Forests and Climate Change (MoEFCC). A major issue was the impact on the wintering habitat of the Black-Necked Crane (Grus nigricollis), endemic to the region. The crane is considered sacred by the Monpa people, as an embodiment of the 6th Dalai Lama who was from Tawang and wrote about the bird in his poetry. The NGT noted that the project - promoted by the Noida-based steel conglomerate LNJ Bhilwara Group - did not consider its impact on the habitat of the crane. It is considered 'vulnerable' in the IUCN's list of endangered species and is listed in schedule 1 of the Wildlife (Prohibition) Act 1972. SMRF general secretary Lama Lobsang Gyatso said, "The NGT's decision to suspend work on the project has led those with vested interest in the state to suddenly look at us as a powerful enemy." ${ }^{8}$ Corruption is also alleged. According to Gyatso, "it is clear to the local people that while somebody powerful is making money on these projects, they have not only been unable to provide electricity but are also degrading the environment they live in." ${ }^{8}$ The week before May 2, Gyatso was arrested twice for reasons he said are "linked to not only the NGT decision but also our plan to take legal recourse for other hydel projects." He explained that he had been locked up in Tawang police station since his rearrest on April 28. On May 2, he was taken to the court of the district magistrate for his bail application. A large number of villagers and lamas assembled in front of the police station seeking his release. He was denied bail. Already angry at the district administration, the crowd of c.200 people moved towards the police station and were fired on with live ammunition rather than tear gas or rubber bullets. A woman hit on the forehead. The other dead was a student at the Tawang monastery. By mid-afternoon, Section 144 orders under were in place and Tawang town and the

\footnotetext{
${ }^{9}$ http://www.cao-ombudsman.org/cases/documentlinks/documents/CAMIF CAOAssessmentReport Jan2014EnglishFINAL.pdf

${ }_{10} \mathrm{https://ejatlas.org/conflict/violence-against-buddhist-monks-opposing-dams-in-tawang-arunachal-pradesh-india}$

11 http://thewire.in/33410/arrested-over-green-tribunals-suspension-of-hydel-project-says-arunachal-anti-dam-activist
} 
army was called in to stage a flag march (a march of army columns and convoys). It was reported that Chief Minister Kalikho Pul, who was in New Delhi, ordered a judicial inquiry into the firing. Pul also announced payments be made to the family of those killed. Local MP and Union Minister of State for Home, Kiren Rijiju, was said to have called up the Tawang deputy commissioner and SP, downplaying the situation and relying on army actions. The National Alliance of People's Movement demanded an official commission of enquiry.

(6) Las Bambas is a very large mining project at 4,000 metres in a remote Quechua speaking region of Apurímac in southern Peru. ${ }^{12}$ Some 49 communities are affected, and six within the mining complex (Fuerabamba, Huancuire, Pamputa, Chicñahui, Pumamarca and Cconccacca). Many residents live in poverty and the mine has recently started production. The project is located in one of the most important mineral reserves in the country for copper, gold, silver and iron. The copper reserves alone are thought to be 40.5 million tons. Since reserves were discovered, exploration has been carried out by private firms and by the state. In 2003 and 2004 the government auctioned the concessions and Xstrata AG from Swtizerland (also active in Tintaya in the neighboring department of Cuzco in another large and controversial copper mine) won, offering US\$121 million for mining rights. The contract between the company and the state was signed in October 2004. The communities have objected to the auction alleging lack of information and the need for popular consultation. From 2005 until 2011, Xtrata conducted exploratory works, and then the EIA (Evaluación de Impacto Ambiental) was approved. The whole process of auction, exploration and exploitation has been accompanied by complaints by the communities, particularly after 2014 when Xtrata sold the mine for US\$5,850 million to the consortium MMG Ltd, an external subsidiary of China Minmetals Corporation. The communities complain that the new company does not fulfill the agreements made with Xtrata. In 2015 they resorted to direct action, detaining one hundred workers working on contract in the mine, and also striking. Some of the demands from the communities are that jobs should be given to local people, that they should be paid for the 'social licence' in allowing water to be used, and receive royalties totaling of $10 \%$ of profits. They also hope for tree plantations across 33 communities. So there are two different arguments in this case: the insistence of territorial rights that must be protected by previous consultations, and the same time (once this very large project gets going) the demand for compensation and jobs.

The Las Bambas open cast project is also considering building a plant for processing copper ores in the upper Challhuahuacho river basin. Mining was already underway in 2016 and expanding Peru's copper extraction. A plan for a mineroduct of $206 \mathrm{~km}$ through the Department of Cuzco (to Antapaccay, another copper mine belonging to Xtrata, which is now owned by Glencore) has caused further conflicts with local communities along the route. The mineroduct was eventually ditched, in favor of a plant in Las Bambas and eventually a railway to the harbour of Matarani, $295 \mathrm{~km}$ away. For the time being, before the railway is built, the reality will be a very intense traffic of trucks on the poor road network, which links small villages and farming áreas. The life of the mine will be at least 20 years. At the end of September 2015, in Las Bambas there was a strong protest against the processing plant with several peasants killed by the police (and also some policemen killed in a car accident). One year later, Quintino Cereceda Huisa, from the community of Choquecca, died in a new protest on 14 October 2016. Quintino lost his life in a clash with the police through a shot to the head. Other comuneros were wounded or beaten up, as reported in La República (Lima) on 16 October. ${ }^{13}$ His wife Antonia Huillca is reported to have kept vigil over the body for nearly two days, accompanied by 400 comuneros while waiting for the judicial authorities to arrive.

\section{Methods for the study of social metabolism}

The economy may be described in terms of economic indicators such as GDP growth, the savings ratio, budget deficit as percentage of GDP, current account balance in the external sector, and so on. Social

\footnotetext{
12 https://ejatlas.org/conflict/las-bambas-peru

${ }_{13}$ http://larepublica.pe/impresa/politica/812371-aqui-estoy-en-lo-alto-del-cerro-junto-al-cadaver-de-mi-esposo
} 
factors may be taken into account, as in the Human Development Index, which nevertheless correlates closely with GDP per capita and leaves aside environmental and cultural losses. The economy may also be described in terms of physical indicators. Economic, social, and physical indicators are non-equivalent descriptions, they may move in different directions.

\section{MEFA: Material and Energy Flows Accounting}

MEFA (material and energy flows accounting) is a set of methods for describing and analysing socioeconomic metabolism. MEFA examines economies as systems that reproduce themselves not only socially and culturally, but also physically through a continuous exchange of energy and matter with their natural environments and with other socio-economic systems. Material flow accounts draw on methodologies established by the research group led by Marina Fischer-Kowalski (1997) in Vienna (Haberl and FischerKowalski, 2015), and other groups over the past thirty years.

In material flows accounting, we first calculate the domestic extraction (in tons per year), divided into biomass, minerals for building materials, mineral ores for metals, and fossil fuels. These measures exhibit different levels and trends in different countries. Domestic extraction is denoted DE. The DMC (domestic material consumption) is equal to DE plus imports minus exports. Physical imports and exports means all imported and exported commodities in tons. The Physical Trade Balance (PTB) is the quantity of physical imports minus that of physical exports. Such accounts (including also carbon or energy 'rucksacks', 'virtual' water, and 'embodied HANPP'; see below) are relevant to understanding current ecological distribution conflicts and also for answering historical and current questions on ecologically unequal exchange.

Energy flow accounting (EFA) is an integral part of the analysis of social metabolism. Primary and final energy delivered are usually classified in statistics according to their source. Such energy flows are also unequally distributed, and they have been creating conflicts not only over coal mining, gas fracking, oil extraction and nuclear power but also over hydroelectricity. Notice that energy accounts are calculated separately from material flows. The idea of linking economic history to the use of energy in this way goes back to Wilhelm Ostwald and later Leslie White and other authors, but it was not until the 1980s that there was an upsurge in serious historical interest in the use of energy in the economy. The most interesting EFA indicator is that of Energy Return on Energy Input (EROI). EROI is a useful coefficient for assessing the increasing costs of obtaining energy, for instance in developing tar sands or heavy oil in Alberta, Canada, or the Orinoco Delta, Venezuela, or when extracting oil from the bottom of the sea (as in Brazil's pre-sal) or by natural gas fracking, and not least in producing agro-fuels such as those derived from sugarcane or Jatropha curcas. An economic-ecological history would trace the changes in EROI over the years, observing at first an improvement as biomass energy (fuelwood, charcoal) is replaced or supplemented by fossil fuels and later a decline, as procuring energy will require increasing amounts of energy inputs.

\section{HANPP: Human appropriation of net primary production}

HANPP (human appropriation of net primary production) is calculated in three steps. The first step is to calculate the potential net primary production (NPP) in the natural ecosystems of a given region or country. The second step is to measure the actual NPP, which is normally less than potential NPP, because of agricultural simplification and soil sealing. Finally, to quantify the part of actual NPP that is used by humans and their domesticates (cattle, etc.) relative to potential NPP. This is the HANPP, which is thus an index of pressure on biodiversity, as a higher HANPP means less biomass available for 'wild' species (Haberl et al., 2007).

In India, due to very high population density (400 person per sq. km.) and land conversion, a relatively high use of biomass per capita, and relatively small imports, the HANPP is very high (compared to South America with only 25 persons per sq.km.). Simron Singh et al. (2012) estimated it at 73\%, compared to about $40 \%$ in the EU (with comparable population densities) and only $24 \%$ in Japan (which imports much biomass). The HANPP in South America is relatively low but it is increasing because of deforestation for cattle-raising and crop production for internal consumption and for exports in Brazil, Argentina, and elsewhere. We can also ask which people get the HANPP, demonstrating its unequal appropriation (Temper, 2016). 


\section{Social metabolism, international trade and environmental conflicts in South America and India}

Going back to the six introductory cases, we see that in the Philippines the EJAtlas (which is work in progress) lists we have 37 cases of conflict (of which in one third, 12, one or more killings are reported) by November 2016. In Honduras there are 17 cases (with killings reported in 5 of them, the most in one case of land grabbing). In Guatemala we have, respectively, 23 and 14, and in Peru, 73 and 24. Altogether in the EJAtlas (Table 2) we list 1,900 conflicts by November 2016, with 247 cases (i.e. 13 per cent) reporting one or more murders of environmental defenders. Since in the database the starting date of the conflict is usually registered, we can begin to establish a timeline for such cases.

Fine-grained future analyses of the social metabolism and the quantity, type and outcomes of environmental conflicts in particular countries will be no doubt be important and revealing. But in this article (whose main aim is to show the broad links between changing social metabolism and international and internal ecological distribution conflicts) we prefer to trace a comparison between two large subcontinents.

The positions of the two subcontinents, South America and India in South Asia, are quite different for international trade and their internal metabolism. South America is a very large net exporter in weight. Its national economies show persistent 'physical trade deficits' in terms of material flows, while in recent years (2013-15) they have not even managed to pay for imports, and have negative trade balances. Even when the terms of trade were relatively favorable, as in the first decade of the twentieth century, South America's exports were, per ton, much cheaper than imports.

In South America, the volume of external trade is high compared to the extraction of materials, while India is much more self-sufficient. India as a whole imports a little bit more than it exports (in tons). Its trade account (in money terms) has recorded deficits since 1980 due to the growth of imports, particularly of crude oil, gold, and silver. India as a whole is not subject to 'ecologically unequal trade' in terms of unequal exchanges of material flows. However, internally some parts of India provide raw materials to the rest of the economy at low prices. There is thus an internal ecological-economic colonialism or, in other words, internal ecologically unequal trade (in terms of material flows).

We focus on the trends in material flows of the economies of India and South America since 1970, comparing these trends and linking them to ecological conflicts and resistance movements. In India, the per capita level of material extraction is low, but there are many conflicts, in part due to the high population density. Extraction will tend to grow in correspondence with economic growth. Imports (in tons) will also grow somewhat, probably more than exports. In South America, the level of extraction per capita is more than twice as large as in India, and the Physical Trade Deficit (imports minus exports, in tons) has grown fourfold in forty years. However, there is currently a clear trend in South America for material flows to stop growing, or at least to grow much more slowly.

In a recent article, the Physical Trade Balances of five South American economies (Argentina, Brazil, Colombia, Ecuador and Peru) were analyzed, country by country, using a long time series (Samaniego, Vallejo and Martinez-Alier, 2017). Both exports and imports (measured in tons) increased but exports were consistently much larger than imports. Such large Physical Trade Deficits persisted in the 1990s and 2000s despite the fact that export prices improved. By 2013-14, export prices declined (because of overproduction combined with a slowdown of China's economy). The exports could no longer pay for imports, and some countries started to show commercial deficits (in financial terms). Some of them devalued, others (like Ecuador, which uses the US dollar) could opt only for tariffs on imports. The five countries have different degrees of specialization in the basket of export commodities, and they also have different policies as regards profit repatriation for foreign direct investment. Nevertheless, the 'post-extractivist' arguments are gaining weight in South American countries in opposition to the economic enthusiasm that was generated by improved terms of trade at the beginning of the twenty-first century. There is no room here to present all the evidence regarding South America's external trade (cf. Dorninger and Eisenmenger, 2016), but the relevance of an 'ecological Prebisch thesis', building on Prebisch's work at CEPAL (the United National Economic Commission for Latin America) conducted in the 1950s and 1960s, is stronger than ever (Pérez-Rincon, 
2006). However, for India as a whole this argument on international terms of trade is not relevant, although it would be relevant for the accounts of Jharkhand, Odisha, and Chhattisgarh, i.e. parts of the country which are subject to internal ecological-economic colonialism.

As explained above, Material Flow Analysis (MFA) aims to complement the system of national accounts with a system of biophysical national accounts using tons per year as the key unit of measurement. This methodology provides a picture of the physical dimension of the economy, where the total turnover of materials of the socio-economic system can be analysed historically or at a given point in time through accounts of the flows of inputs (e.g., tons of biomass, fossil fuels, construction minerals) or outputs (e.g., tons of materials exported, waste or pollutant generated). We focus on the input side by taking into account all materials that enter into the national economy, and we acknowledge also the physical dimension of foreign trade (Hornborg, 1998, 2006, 2009). MFA provides a picture of the overall development of the pressures exerted by an economy on its base of renewable and non-renewable resources.

\section{South America}

MFAs have been conducted in most OECD countries and also in Latin America. For instance, the material flows of Argentina were analyzed by Pérez Manrique et al. (2013) and those of Colombia, Mexico, Ecuador, and Latin America as a whole by other authors (González-Martinez and Schandl, 2008; Russi et al. 2008; Vallejo et al. 2011; West and Schandl, 2013). In Argentina, the recent increase in some forms of metal ore and biomass extraction (particularly soybeans, covering some 20 million ha) has led to new types of conflicts. In the case of soybeans this is not only because of land use changes and eviction of indigenous peoples but also because of fumigation with glyphosate. This last issue is so salient that it is mentioned in Pope Francis' encyclical, Laudato si (Pope Francis 2015: paragraph 135).

Figure 1 shows the trends in extraction of materials in Latin America (including Mexico) over the last 40 years, up until 2008. By 2008 extraction reached more than ten tons per capita, of which over ten per cent was exported. Exports significantly exceeded imports (Figure 2).

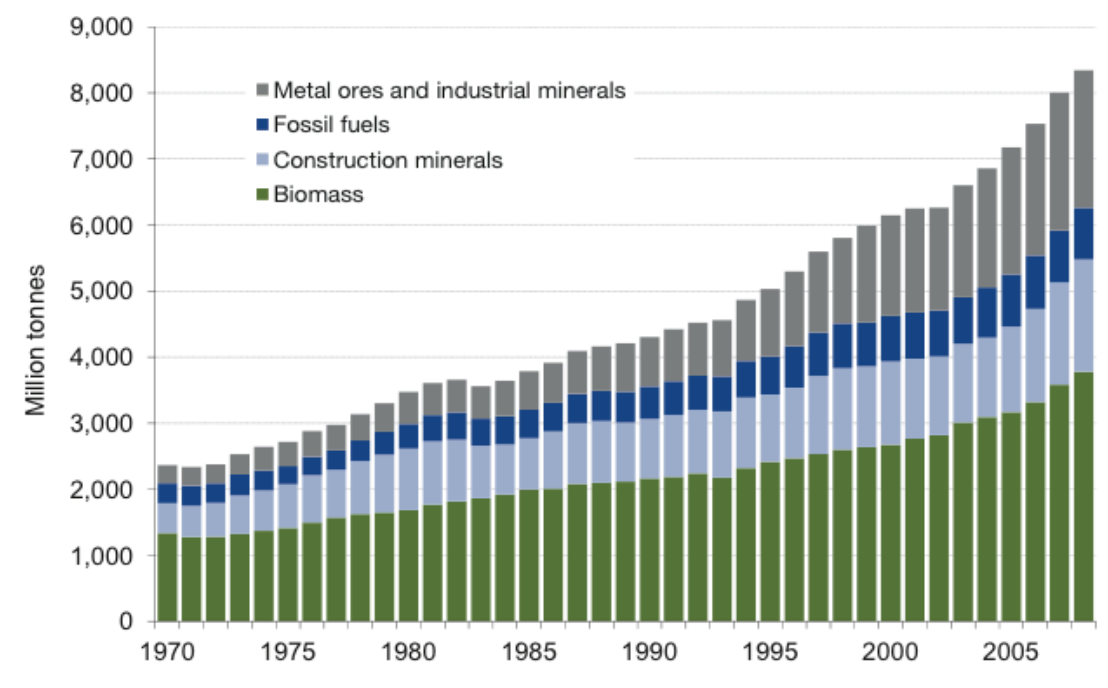

Figure 1: Domestic extraction in Latin America by major category of material for the years 1970-2008, in million tons (source: West and Schandl, 2013)

Overall there was a fourfold increase in material flows between 1970 and 2008 for both domestic consumption and exports. The Latin American economy has certainly not become 'dematerialized.' We can compare such trends with those of other continents such as Europe, where the rate of increase of material 
extraction has been much lower, or with India, which has a lower rate of per capita material extraction than Latin America and which is not at all a net exporter in physical terms (Singh et al., 2012; see next section). Such physical indicators are useful to characterize the economic structure of countries or regions. Note in Figure 1 that Mexico has a pattern of external trade somewhat different from that of South America.

As explained above, the Physical Trade Balance (PTB) is the difference between the number of tons of materials that are imported from an economy and the number of tons that are exported. If exports exceed imports in physical terms we call it a Physical Trade Deficit: the country is losing 'substance.' The Monetary Trade Balance (MTB) is the difference between how much is paid for the imports and how much is earned by exports in monetary terms. South American economies have had a persistent and rapidly increasing physical trade deficit (West and Schandl, 2013). Exports in tons are larger than imports in tons, resulting in a physical 'deficit' in the same sense that would be applied to a tree plantation in which the rate of growth is slower than the harvest rate. Figure 2 presents the annual PTB of Latin America (including Mexico) by type of material from 1970 to 2008. Notice in this figure the increased physical trade deficit for metal ores and industrial minerals, which reflects the growing pressure to extract and export these materials. Latin America as a whole [including Mexico] has about 620 million people, so the Physical Trade Deficit is over one ton per capita/yr. It is unlikely that this deficit will grow much in the next decades - even maintaining this level implies very heavy pressure at the commodity extraction frontiers.

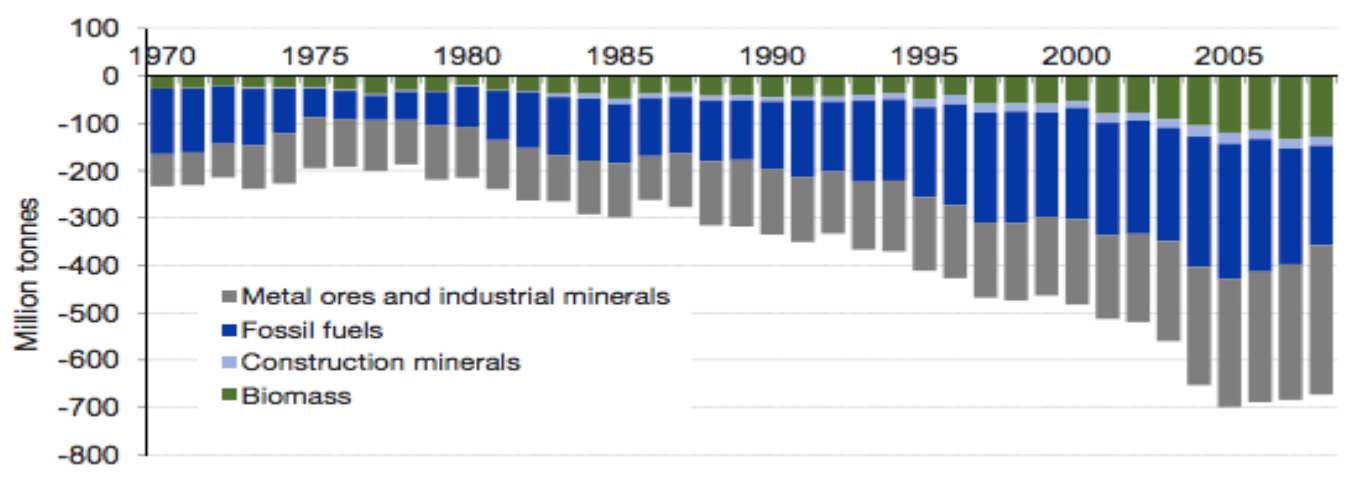

Figure 2: Latin America's physical trade deficits (imports minus exports) in million tons, 19702008 (source: West and Schandl, 2013).

We admit that, in terms of environmental impacts, one ton of uranium is very different from one ton of sand and gravel, as is one ton of cellulose from one ton of shrimp. However, we focus here on trends within broad material categories rather than on specific commodities. There are internal and external pressures to increase the extraction of materials, for both domestic use and export. Such increasing pressures to extract materials displace the commodity frontiers to new territories, often inhabited by peasant and indigenous groups who complain and resist accordingly (Moore, 2000).

The concept of 'ecologically unequal exchange' challenges the argument that exports from developing nations foster economic growth and development and points to the physical and socio-environmental tradeoffs at play (Bunker 2007; Hornborg 1998; Muradian and Martinez-Alier 2001). We can measure ecologically unequal trade in terms of the asymmetric flows of various physical metrics such as hours of labor, hectares of land, joules or calories, tons of materials, or water footprints. When all or most indicators point in a similar direction we can state that there was an unequal exchange (Hornborg 2006). Ecologically unequal exchange arises from the structural fact that the metropolitan regions or countries require for their metabolism increasing amounts of energy and materials at low prices and that they have enough power to impose and maintain unequal terms of trade.

The terms of trade are persistently negative for South America as a whole and for most countries taken 
individually: one ton of imports is always from two to five times more expensive than one ton of exports. Clearly, not all continents can have the same physical trade profile. Thus, in the EU and in Japan, exports are more expensive than imports per ton. This is another way of saying that flows of energy and materials at relatively low prices must flow from the peripheries to the industrial metropolis (Hornborg, 1998).

The terms of trade improved somewhat in the first decade of the twenty-first century, fuelling a wave of optimism in South America regarding economic growth, but then they again began deteriorating. Currently, the large physical exports can scarcely pay for the imports in most South American countries. In 2013 or 2014, or in both years, there were commercial deficits in Brazil, Colombia, Ecuador, Peru, and other countries, while Argentina's commercial surplus was dwindling and finally turned into a deficit in 2015 (Samaniego et al., 2017).

Awareness of ecologically unequal trade giving rise to an ecological debt or environmental liabilities is not new in South America, and the injustice is now compounded by climate change. This has been reaffirmed in very explicit terms by Pope Francis, who comes from Argentina. Paragaph 51 of Laudato si draws on EJOs' and academic literature produced since 1991 in the region which had a high point in 2000 with the Jubilee South campaign. Paragraph 51 reads in the English version:

A true "ecological debt" exists, particularly between the global north and south, connected to commercial imbalances with effects on the environment and the disproportionate use of natural resources by certain countries over long periods of time. The export of raw materials to satisfy markets in the industrialized north has caused harm locally, as for example in mercury pollution in gold mining or sulphur dioxide pollution in copper mining. There is a pressing need to calculate the use of environmental space throughout the world for depositing gas residues which have been accumulating for two centuries and have created a situation which currently affects all the countries of the world. The warming caused by huge consumption on the part of some rich countries has repercussions on the poorest areas of the world... (Pope Francis 2015).

We dare to emphasize the word disproportionate, so closely linked to the claims from the US environmental justice movement since its beginnings in the 1980s.

India

Following the example of Japan over twenty-five years until 2016, economic growth has faltered in many affluent countries since 2008, less by design than because of the economic crisis, while in most of the BRICs and also in other countries, there has been sustained growth. Poverty in terms of income per capita has declined in all these countries, including India. This growth is achieved at great environmental and social cost. Peasants are squeezed off the land, while tribal peoples in India and indigenous peoples elsewhere are being displaced because they happen to live at the commodity extraction frontiers. Biodiversity is rapidly decreasing, and globally the concentration of carbon dioxide in the atmosphere is increasing. There is an increasing awareness of climate change at local level in countries of the South. In the EJAtlas we have recorded the complaints by Kuna people in Panama who feel they have to vacate already some of the islands because of sea level rise, and the struggle in Sompeta in Andhra Pradesh against a coal fired power plant explicitly combining "leave coal in the hole" proposals with local collective investment in solar energy. ${ }^{14}$

This is the background to a study of India's material flows from 1961 to 2008, carried out by Singh et al. (2012) and which points to a much more material-intensive future than the past. India still consumes less fossil fuels, less building materials, and less mineral ores per capita than most other countries. To reach a per capita physical profile similar to Latin America, which has only half the population, the total material flows of India - whether based on local extraction or additionally on imports of coal from Australia and oil and gas

14 https://ejatlas.org/conflict/comunidades-kuna-yala-frente-al-cambio-climatico, $\quad$ https://ejatlas.org/conflict/sompetapower-plant. 
from the West Asia - would have to multiply by a factor of four. A slight advantage of India may be its high population density, which diminishes internal transport needs. In future, another possible advantage could be the feasibility of proceeding directly to solar energy for rural electrification.

In the 1960s, about three-quarters of India's total material consumption consisted of biomass, while construction materials were second in importance. In India, biomass is fundamental to human and domestic animal subsistence. The domestic animals provide milk and dung. In contrast, in South American countries like Argentina and Brazil, a lot of the biomass is converted into meat consumption or exports. In India in the 1960s, fossil fuels and industrial minerals and ores were insignificant in relation to the total flows, but in the course of the almost 40 years under study, the material flows changed in quantity and composition. The use of biomass doubled, but fossil fuel consumption multiplied by a factor of 12.2, industrial minerals and ores by a factor of 8.6, and construction materials by a factor of 9.1 (Singh et al., 2012).

Until the 1980s the population of India grew at a slightly faster pace than material throughput. Throughout the 1960s and 1970s, material use remained at a low and slowly declining level of less than 3 t/cap/yr. Only in the early 1980s - ten years before the neoliberal finance minister Manmohan Singh was installed in 1991 - did sustained growth in per capita material consumption set in, increasing to 4.3 t/cap/yr after accelerating from 2004 onwards. Taking into account further economic growth from 2008 to 2015 , material consumption in India has now definitely reached over 5t/cap/yr and is growing quickly. In comparison, per capita material consumption in EU countries is about 15 tons per person/year.

In the EU imports are very significant, exceeding exports in tons by a factor of 4. Conversely, in South America exports exceed imports in tons by a factor of 2 to 4 or even 5, depending on the country (Mexico has a different pattern because of its maquila industry and also because of its imports of maize, although it is aiming to again become a large exporter of fossil fuels after privatizing Pemex). In contrast, India's external trade is more or less balanced in physical terms, and in any case external trade is a small part of its physical economy (Singh et al., 2012). However, some states within India have a considerable Physical Trade Deficit, and these states (such as Odisha, Jarkhand, and also Goa because of iron ores) have seen significant ecological distribution conflicts. They are victims of an ecologically unequal exchange, although the notion does not apply to India as a whole. Perhaps internal ecological colonialism is the appropriate term.

Across the world, construction minerals are abundant, and so scarcity and conflicts over these materials are usually regional phenomena (Singh et al., 2012). However many regions of India have illegal groups sourcing and controlling the trade in building sand. Sand and gravel mining for the building industry from rivers and beaches has become an Indian environmental issue. It is forbidden in many instances, and takes place illegally, hence the name "sand mafias" (A.A. Singh et al. 2010). There are also "stone-crusher" mafias in many regions, as reported recently in The Hindu (12 November 2006): "According to eyewitnesses, Dharmendra Singh, 35, working for Hindi daily Dainik Bhaskar, was at a tea stall outside his house in Amra Talab area in Sasaram when three motorcycle-borne men fired at him from close range. He was hit on his chest and abdomen... Local journalists told The Hindu that Mr. Singh might have been killed by the stonecrusher mafia which has been active in the area for long in spite of the massive crackdown on their operations."

The trends in total and per-capita domestic material consumption in India (extraction plus imports minus exports) are summarized in Figure 3. Notice that in Figure 1 we provided rates of Domestic Extraction for Latin America. For India we estimate rates of Domestic Consumption (extraction plus imports minus exports), which in this case are very similar to rates of extraction because of the physical irrelevance of external trade for the economy of India as a whole. We calculated total (Figure 3) and per capita figures (Figure 4).

\section{From ecological economics to political ecology}

Like industrial ecology, ecological economics studies the social metabolism, using methods developed over the last twenty years. Political ecology studies socio-environmental conflicts, also conceptualized as ecological distribution conflicts. The industrial economy has reached a very high level of material consumption per capita and is not 'dematerializing' in per capita terms. Therefore, there are increasing local 
and global conflicts over the sharing of the burdens of pollution, including the greenhouse effect, and over access to natural resources. Such conflicts represent what has been called "the environmentalism of the poor", also referred to as popular environmentalism, livelihood ecology, liberation ecology, and the environmental justice movement. These environmental movements may help to move the economy toward more social justice and ecological sustainability (Martinez-Alier, 2002).

Focusing on comparative case studies, the field of political ecology has studied many environmental conflicts in Southern countries since the 1980s (Robbins, 2004). Going beyond case studies, some researchers have begun to compile statistics on conflicts over resource extraction and waste disposal. For instance, Gerber (2011) analysed a number of conflicts regarding industrial tree plantations for wood, palm oil, and rubber production, which are among the fastest growing monocultures and are currently being promoted as carbon sinks and energy producers. Such plantations have generated a large number of conflicts between companies and local populations.

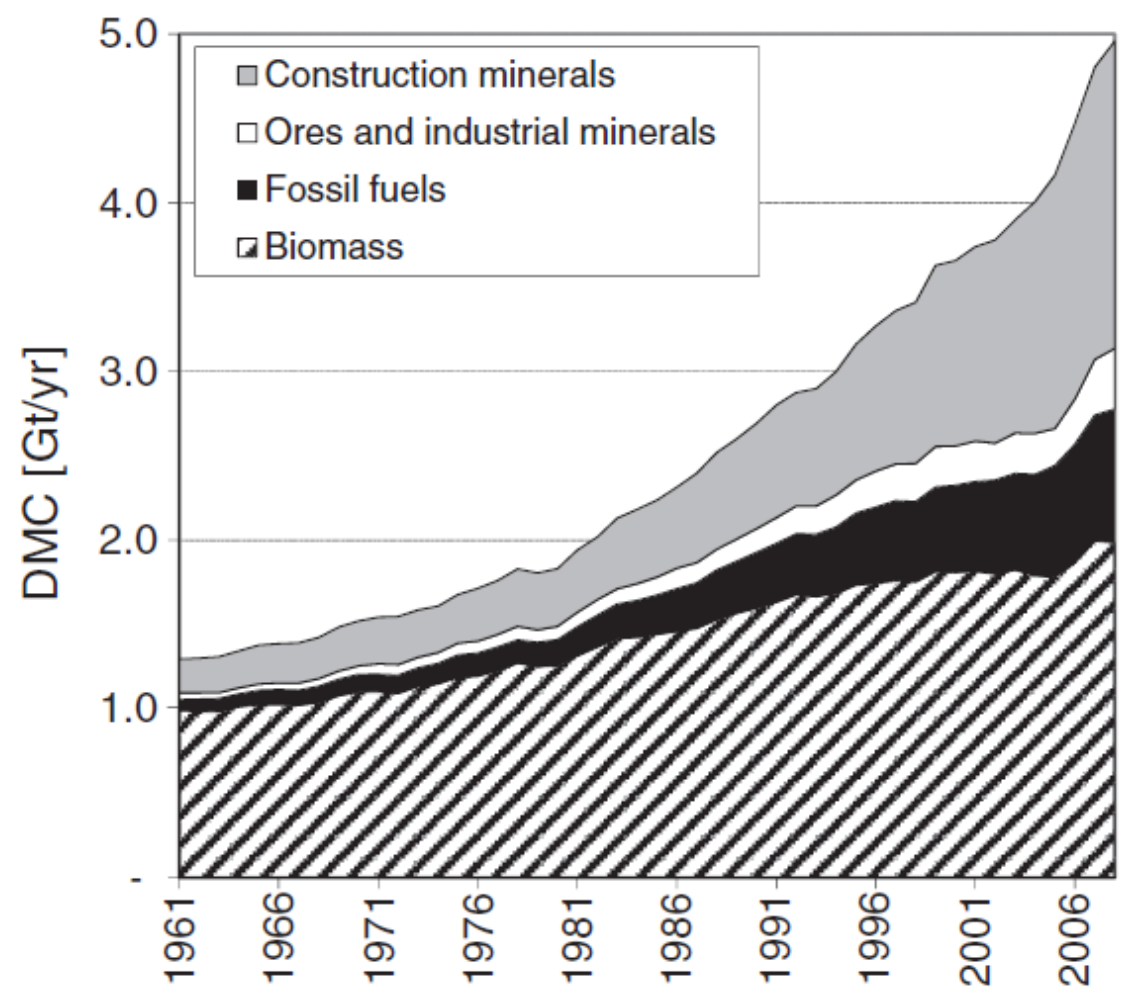

Figure 3: Material flow accounts of India 1961-2008. Domestic consumption in gigatons per year (Singh et al. 2012).

We consider here not only local conflicts but also the type of conflicts at national or regional level that arise from 'ecologically unequal trade.' Ecological distribution conflicts are struggles at several scales over the burdens of pollution or over the sacrifices made to extract resources, and they arise from inequalities of income and power (Martinez-Alier and O'Connor, 1996). The concept of ecological distribution conflicts has emerged at the intersection of ecological economics and political ecology, linking the emergence of environmental conflicts in the global South with the growth of the metabolism of societies in the global North, which now includes parts of China and India (Hornborg, 1998). Political ecology focuses on the exercise of power in environmental conflicts, that is on who has the power to impose decisions on resource extraction and trade, river dams, land use, pollution levels, or biodiversity loss, and, more importantly, on who 
has the power to determine the procedures to impose such decisions, accommodating or excluding different languages of valuation (Martinez-Alier 2002, 2009; Robbins 2004).

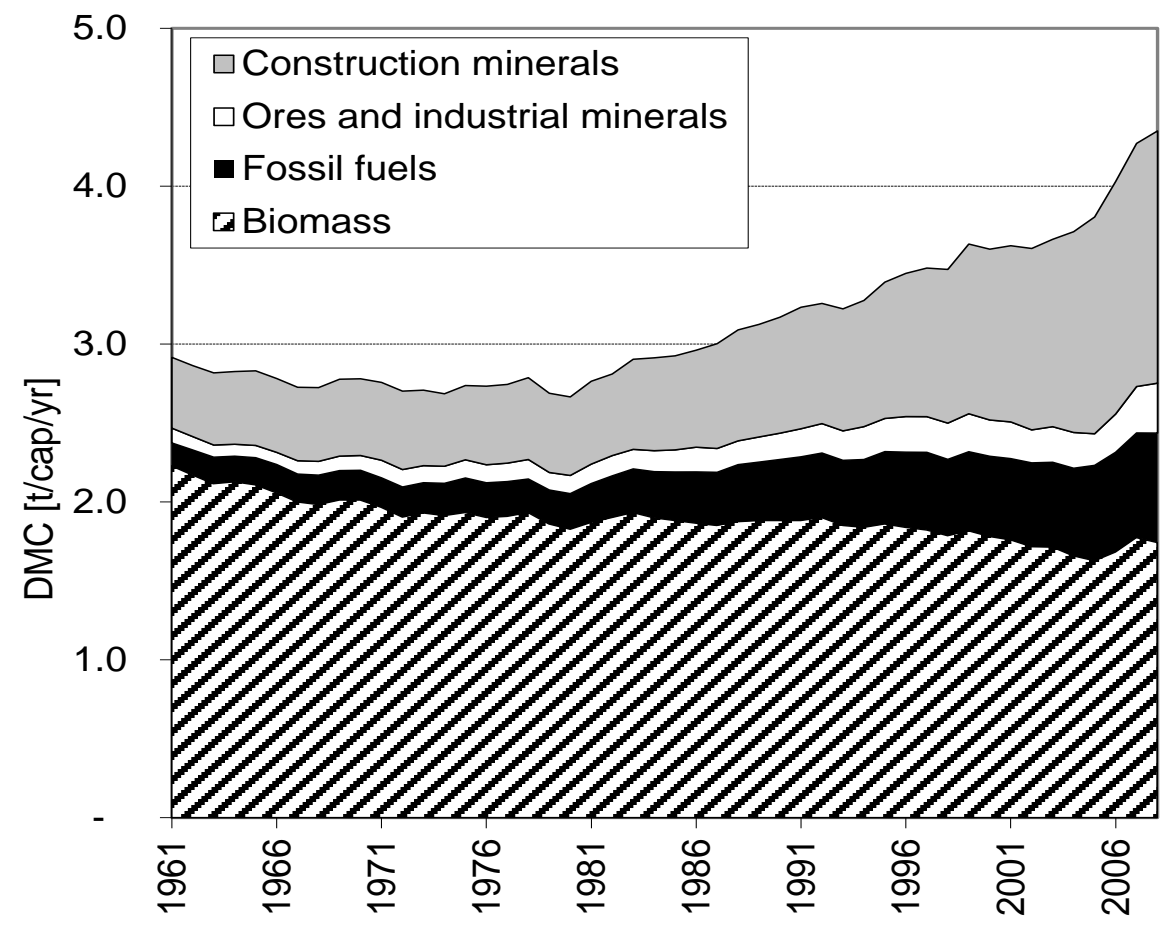

Figure 4. Domestic material consumption in India, tons per capita/year (Singh et al., 2012).

Ecological distribution conflicts emerge from structural asymmetries in the burdens of pollution and in the access to natural resources, grounded in unequal local and international distributions of power and income, and in social inequalities of ethnicity, caste, social class, and gender (Martinez-Alier et al. 2011). Sometimes local actors demand redistribution, leading to conflicts which may be part of, or conducive to, more inclusive gender, class, caste, or ethnic struggles, even at the national level.

Not all conflicts are born from immediate metabolic needs. Demand for certain commodities like gold arises in part from the search for investment opportunities that allow further speculation. Other metals such as copper can also be stored and used as guarantees for speculative loans; however, speculators in industrial metals have suffered great losses from the decline of prices in 2014-2015, caused by excessive world supply and declining demand in China. Nevertheless, beyond financial speculation, energy carriers (coal, gas, oil, biomass) and metallic minerals are essential inputs for the industrial economy and their aggregate use grows more or less in proportion to the growth of the economy.

Economic change generally implies benefits for some groups at the expense of other existing or future groups. Externalities can be positive (like the free environmental services provided by a forest) or negative. Negative externalities are not seen here as market failures but rather as (provisional) successes in cost-shifting (Kapp 1950) that often give rise to complaints from environmental justice movements, as well as the environmental and territorial concerns of the poor, marginalized, and indigenous. Activists in many countries of the South understand and use the concept of the "environmentalism of the poor." In India, Sunita Narain writes often on the environmentalism of the poor (e.g. Narain, 2011). 
In the environmentalism of the poor, as in environmental justice movements in general, it is important to recognise the contribution that women make in poor communities, both rural and urban (Agarwal, 1992). Women more often collect water, gather wood, look for medicinal plants, tend to domestic animals, and grow crops, and therefore have greater knowledge and awareness of their community's direct dependence on the natural environment. This does not mean that women experience an empathy with nature which is denied to men for biological reasons. The argument is based only on social roles. In urban contexts, it is generally women who assume leading positions in environmental justice conflicts (in contrast, for instance, to labor union struggles), regarding complaints against issues such as waste dumping or the pollution of water or air. Women are often the main actors of such environmental movements. The EJAtlas is a good source for researching the many cases of women's leadership in environmental conflicts.

The environmentalism of the poor emerges in situations where the environment is a source of livelihood. This is reinforced by other values, such as the defence of indigenous territorial rights - e.g., appealing to Convention 169 of ILO or adivasi rights in India - or claiming the sacredness of particular elements of nature such as a mountain, a forest, or even a tree or emotional attachment to customary living spaces. When livelihood is threatened, those affected will be motivated to protest, provided that there is a sufficient degree of democracy and they are not silenced by fear, as is often the case. Indeed, a clean and safe environment is a necessity for all humans, rather than a luxury good (Bandyopadhyay and Shiva, 1988).

In such conflicts, a variety of 'valuation languages' are deployed. Some of them were perhaps more powerful in the past (e.g., those referring to livelihood or sacredness) than in this era of generalized faith in the market, where the fetishism of fictitious commodities is increasingly dominant in schemes for payment for environmental services. One wonders, for instance, how effective it still is in India to oppose a mining project or dam by referring to the sacredness of a 'sacred grove.' In India attempts to compensate for damages in resource extraction conflicts are based on ascertaining the so-called Net Present Value (in money terms) of the foregone products and services from forests (Temper and Martinez-Alier, 2014). This is a peculiarity of Indian state administration. Other valuation languages apart from money compensation, such as human rights, indigenous territorial rights, protests against 'environmental racism', and even the Rights of Nature (as in art. 71 of the 2008 Constitution of Ecuador), are perhaps gaining strength across the world. At the international level, complaints regarding ecologically unequal trade could gain force.

A socio-metabolic approach shows that material inputs into the economy ultimately become outputs in the form of waste, except for the part that accumulates as a stock, as in buildings. The main output in volume, apart from waste water, is carbon dioxide from the burning of fossil fuels, the excessive production of which is a major source of climate change. Solid wastes produced by the economy are mostly disposed of locally in landfills or (controversial) incinerators, but they are sometimes exported to distant regions or countries. The life cycles of all goods can be analyzed in terms of 'commodity chains', i.e. from cradle to grave or from point of extraction to waste disposal (Raikes et al., 2000). Ecological distribution conflicts occur at different stages in the commodity chains, from extraction to waste disposal, since different social actors - peasant or tribal groups, national or multinational companies, national governments, local or international NGOs, consumer groups, urban dwellers - have different stakes and interests to defend. Table 1 classifies environmental conflicts according to the stage of the commodity chains at which they occur and their geographical reach. Sometimes local conflicts become 'glocal', i.e. well known outside the territory in question, as in the case of the Dongria Kondh vs. Vedanta in Odisha (Padel and Das, 2010) or the Chevron-Texaco case in Ecuador, or the Agua Zarca case in Honduras in 2016 (though not (yet?) the King-King case in South Mindanao).

\section{Some results from the EJAtlas}

In the EJAtlas (www.ejatlas.org) we have compiled 1,900 conflict cases as of November 2016 and we are continuing to collect and map conflicts. We add conflicts regularly but we also eliminate duplicates from time to time. We classify the conflicts, to start with, in only one of the main ten categories or commodities in question, as in the following list: 
- Nuclear: uranium extraction; nuclear power plants; nuclear waste storage

- Ore and building materials: mineral extraction; mineral processing; tailings

- Waste management: e-waste and other waste import zones; ship-breaking; waste privatisation; waste-pickers; incinerators; landfills; uncontrolled dump sites; industrial; municipal waste

- Biomass: land-grabbing; tree plantations; logging; non-timber products; deforestation; agro-toxics; GMOs; agrofuels; mangroves vs. shrimps; biopiracy and bio-prospecting; intensive food production (monoculture and livestock); fisheries

- Fossil fuels and climate justice/ energy: oil and gas extraction; oil spill; gas flaring; coal extraction; climate change related conflicts (glaciers and low islands); REDD/CDM; windmills; gas fracking

- Transportation and infrastructure: megaprojects, high speed trains

- Water management and hydric justice: dams, water transfers, aquifers, hydroways, desalination

- Biodiversity: invasive species, damage to nature, conservation conflicts

- Industrial and utilities conflicts: factory emissions, industrial pollution

- Tourism facilities: hotels, marinas

\begin{tabular}{|c|c|c|c|}
\hline $\begin{array}{l}\text { Geographical scope } \\
\text { Stage of the } \\
\text { commodity chains }\end{array}$ & Local & $\begin{array}{c}\text { National and } \\
\text { Regional }\end{array}$ & Global \\
\hline Extraction & $\begin{array}{l}\text { Resource conflicts in tribal } \\
\text { areas, such as bauxite mining } \\
\text { in Odisha, coal or uranium } \\
\text { mining in Jharkhand, oil } \\
\text { extraction in the Amazon of } \\
\text { Ecuador or Peru or the Niger } \\
\text { Delta. }\end{array}$ & $\begin{array}{l}\text { Mangrove uprooting, shrimp } \\
\text { aquaculture. } \\
\text { Tree plantations for wood or } \\
\text { paper pulp. } \\
\text { Collapse of fisheries. }\end{array}$ & $\begin{array}{l}\text { Worldwide search for minerals } \\
\text { and fossil fuels at the } \\
\text { 'commodity' frontiers. } \\
\text { Bio-piracy. } \\
\text { Attempts at regulation of } \\
\text { 'corporate accountability'. }\end{array}$ \\
\hline Transport and Trade & $\begin{array}{l}\text { Complaints against urban } \\
\text { motorways or heavy traffic in } \\
\text { rural mining areas because of } \\
\text { noise, pollution, landscape loss. }\end{array}$ & $\begin{array}{l}\text { Inter-basin water transport. } \\
\text { Oil/gas pipelines (e.g. Burma to } \\
\text { Thailand). }\end{array}$ & $\begin{array}{c}\text { Oil spills at sea. } \\
\text { 'Ecologically unequal } \\
\text { exchange' because of large } \\
\text { South to North material flows. }\end{array}$ \\
\hline $\begin{array}{l}\text { Waste disposal and } \\
\text { pollution, post- } \\
\text { consumption }\end{array}$ & $\begin{array}{l}\text { Conflicts over incinerators } \\
\text { (dioxins) or VOCs, NOx, } \\
\text { ozone, particulate matter }\end{array}$ & $\begin{array}{l}\text { Nuclear waste disposal (Gastre in } \\
\text { Patagonia, Argentina). } \\
\text { Ship dismantling (Alang-Sosiya, } \\
\text { Chittagong) }\end{array}$ & $\begin{array}{l}\text { CO2, CFC: causes of climate } \\
\text { change/ ozone layer } \\
\text { destruction / ocean } \\
\text { acidification. POPs even in } \\
\text { remote pristine areas. } \\
\text { Claims of a 'carbon debt', } \\
\text { climate justice }\end{array}$ \\
\hline
\end{tabular}

Table 1: A classification of some ecological distribution conflicts

We also include other types of 'secondary' conflicts (cross cutting categories, if necessary: for instance, failure of a mine tailings dam also becomes a water management conflict). It is laborious but feasible to trace many hundreds of examples of these types of conflicts at a global level and of course also in India and South America, listing the specific commodities in question and the various social actors involved, and trying to 
account for the reasons for the occasionally successful outcomes of struggles against environmentally destructive projects. For instance, in India, because of a combination of local environmental complaints and corruption scandals, the iron export industry was practically brought to a halt in 2011 by the Supreme Court in Karnataka, Goa, and other states. In 2014-2015, India exceptionally became a net importer of iron ores. In Goa, where iron ore extraction had reached 50 million tons per year, the Supreme Court first stopped iron mining, and then decided in April 2014 to allow it, but imposed an annual cap. ${ }^{15}$

\section{Do indigenous groups in Latin America and India disproportionately participate in environmental conflicts?}

This is a question that we can begin to answer, based on the results of the EJAtlas. The answer seems to be 'yes' (for the case of Colombia, see Pérez-Rincón, 2014). We present this finding merely as a hypothesis, in order to trace a theoretical and political connection between global environmental justice and the US environmental justice movement of the 1980s, which emphasized the struggle against 'environmental racism.'

Some results are presented in Table 2. The database form includes a space in which to list the social actors mobilizing in conflicts. Several actors can be listed simultaneously, including 'indigenous or traditional communities' and 'ethnically/racially discriminated communities.'

\begin{tabular}{|c|c|c|c|c|c|c|}
\hline & $\begin{array}{c}\text { Number of } \\
\text { conflicts in } \\
\text { EJAtlas }\end{array}$ & $\begin{array}{c}\text { Success in } \\
\text { environmental } \\
\text { justice }\end{array}$ & $\begin{array}{c}\text { Participation of } \\
\text { indigenous groups } \\
\text { or traditional } \\
\text { communities* }\end{array}$ & $\begin{array}{l}\text { Participation of } \\
\text { ethnically/ } \\
\text { racially } \\
\text { discriminated } \\
\text { communities* }\end{array}$ & $\begin{array}{c}\text { Religious } \\
\text { groups * }\end{array}$ & $\begin{array}{c}\text { Cases with } \\
\text { reported deaths } \\
\text { of } \\
\text { environmental } \\
\text { defenders }\end{array}$ \\
\hline $\begin{array}{c}\text { Total } \\
\text { worldwide }\end{array}$ & 1900 & 332 & 798 & 349 & 219 & 247 \\
\hline $\begin{array}{c}\text { South } \\
\text { America } \\
\text { (selected } \\
\text { countries) }\end{array}$ & 416 & 84 & 203 & 94 & 56 & 78 \\
\hline India & 184 & 25 & 117 & 21 & 19 & 17 \\
\hline
\end{tabular}

Table 2: Environmental conflicts, success rates, participation of indigenous/traditional communities/ ethnically discriminated groups in India, South America. Source: EJAtlas (as of November 2016). 'South America' means Argentina, Brazil, Colombia, Peru, Ecuador, Chile.

*Not mutually exclusive.

The participation of indigenous or traditional communities and ethnically discriminated communities, with some overlap between these two categories, appears to be greater than their relative share of the population as a whole. In South America and India such groups taken together are involved in more than half of the conflicts. In Europe, in contrast, as a glance at the EJAtlas will show (selecting 'indigenous and traditional communities' and/or 'ethnically discriminated communities'), there are very few such cases - some in Scandinavia involving the Sami people. One question would be whether the disproportionate participation of indigenous peoples in environmental conflicts is explained by their location at commodity frontiers, or by an inclination of transnational companies or governments to target them because of their presumed low capacity to resist political pressure. Such disproportionate participation (in relation to the population census)

15 http://www.business-standard.com/article/economy-policy/supreme-court-lifts-ban-on-iron-ore-mining-in-goa114042100501 1.html. Typing "India" and "iron ores" in www.ejatlas.org, returns a set of 12 cases (20 Nov. 2016), a good start for somebody wanting to write a research paper on such conflicts. 
is clear in Argentina and Chile, for instance, and in our view it has to do with the march towards the commodity frontiers where Mapuche and Aymara groups live. Again, interesting comparisons can be made by applying the category of 'environmental racism' developed by the US environmental justice movement since the 1980s.

\section{'Success' in environmental conflicts}

Other types of analysis can be conducted. In the inventory of 1,900 cases (Nov. 2016), 332 were reported as 'successes' (17 per cent) which often means than the investment project that triggered the conflict was stopped. Table 3 shows the number of successful cases bay main category in relation to the total number of conflicts. As within countries, there are differences in the 'success' rate which we cannot explain at present. With more cases, it would be possible to try to determine whether deviations from the 'average' rate of success of 17 per cent significantly depend for some reason on the country in question, or the commodities in question. In the database forms there is much more detailed information, pertaining to over one hundred specific commodities.

\begin{tabular}{|c|c|c|}
\hline Category & Total cases & 'Success' cases \\
\hline $\begin{array}{c}\text { Mineral ores, building } \\
\text { materials }\end{array}$ & 414 & 80 \\
\hline $\begin{array}{c}\text { Fossil fuels /climate } \\
\text { change }\end{array}$ & 361 & 41 \\
\hline $\begin{array}{c}\text { Biomass extraction, land } \\
\text { conflicts }\end{array}$ & 303 & 44 \\
\hline Water management & 278 & 33 \\
\hline Industry and utilities & 145 & 27 \\
\hline $\begin{array}{c}\text { Infrastructures and built } \\
\text { environment }\end{array}$ & 124 & 25 \\
\hline Waste management & 115 & 18 \\
\hline Nuclear energy & 70 & 11 \\
\hline Biodiversity conservation & 47 & 6 \\
\hline Tourist recreation & 43 & \\
\hline
\end{tabular}

Table 3: Number of conflict cases and rates of success per main category in EJAtlas (as of Nov. 2016 with 1900 cases).

The average rate of 'success' may increase or decrease somewhat as more cases are brought into the EJAtlas from areas or categories which are still under-represented. Perhaps 'success' in environmental justice conflicts is more easily achieved in some countries than others. In India only about $11 \%$ of cases in the EJAtlas are so far reported as 'successes', and in South America the rate is higher. The reader can easily go to the EJAtlas and use the Filter function to calculate also the percentages of cases classified (at the Success Level) as 'not sure' or 'failures.' Small differences will not solidly support theories on the relative strength of environmental movements in different, large, regionally heterogeneous countries. However, as we reach an inventory of 3,000 cases worldwide (with better geographical coverage) by the end of 2019, we dare predict that between 450 and 600 will be considered 'successes' in environmental justice. This is encouraging to provide the empirical foundation for a general theory of the growing movement for environmental justice (Martinez-Alier et al., 2016). The database forms, which are freely available in the EJAtlas webpage, provide space to explain the reasons why a conflict is considered a success or a failure (or a 'not sure') for environmental justice. Analysis of this information would help advance a theory of the meaning of 'success' in 
environmental justice conflicts, and also increase our knowledge on whether permanent sustainable alternatives are born from such 'successes.'

Finally, we might ask whether ethnicity is a factor in the rate of success? This is a question that we shall not attempt to answer here. Out of the 1,900 conflicts in the inventory as of November 2016, indigenous, traditional, and/or ethnically discriminated communities take part in about half. Some statistical analysis might be done at a later date.

In general terms, one could ask not only about the factors that explain 'success' - e.g., the nature of the commodities in question, the social groups mobilizing, the political culture of states, and not least the degree of democracy - but whether high rates of success in environmental conflicts is or is not a factor in moving the economy in a more sustainable direction. Moreover, in the EJAtlas inventory there are many cases (about $30 \%$ ) classified as ambiguous ('not sure'), some of which are or have been very close to 'success.' A rate of success in environmental justice conflicts of $20 \%$ or perhaps $25 \%$ is plausible and at the same time it is a good reason for optimism regarding environmental justice and sustainability.

\section{Conclusion}

The energy from fossil fuels is used only once, and new supplies must be obtained from commodity frontiers (Moore, 2000). Similarly, materials are recycled only in part, and therefore, even a non-growing economy would need fresh supplies of e.g. bauxite, copper, and iron ores. The growth in the number of conflicts over resource extraction and waste disposal (of which the internationally most noticeable one is that arising from the excessive emissions of carbon dioxide) is explained to some extent by changes in social metabolism. While India's social metabolism, measured in terms of material flows, is growing rapidly (from a little over 4 tons per capita/year in 2008, Figure 4), South America multiplied the extraction of materials from 1970 to 2008 by a factor of four, increasing it to over 10 tons per capita per year. The continent's material growth nearly stopped in 2015 and it is unlikely that it will grow much again even if South America exits from the current economic crisis. There is a danger, however, that the economic crisis and increasing indebtedness may lead to increasing volumes of exports at low prices and low environmental standards - as Peru and Brazil did in 2014-16 when they dumped copper and iron ore respectively on weak world markets.

We have illustrated the clash between the increasing and changing social metabolism and the livelihood of common people by providing anecdotal evidence regarding some killings of environmental defenders in 2016. The EJAtlas provides many more examples of such infringements of human rights over the years, and there are also the terrible accounts provided by Global Witness that have improving coverage each year. We have then considered comparative data on India and South America to explore the links between social metabolism (i.e. the flows of energy and materials in the economy) and the appearance of different sorts of ecological distribution conflicts. We have emphasized two conspicuous features: ecologically unequal exchange as a characteristic of South America, and internal environmental colonialism in India. We could also have looked in more detail the local resistance movements led by Environmental Justice Organizations (or EJOs), their repertoires of contention, their vocabularies, and the 'valuation languages' deployed by them in particular conflicts (from sacredness and intangible territorial rights to monetary compensation for damages). In a previous article in this journal (Martinez-Alier et al., 2014), we began to compile the grassroots vocabulary of the global environmental justice movement.

We have shown that South America and India have rather different profiles in terms of material flows, which could be interpreted as differences in terms of the stages of development that they have reached. Considering all materials, South America has reached a level of extraction of over 10 tons per person/year. It is unlikely that this will increase much. A substantial part is destined for exports, which are in tons much larger than imports. This is diametrically different from the European Unions, where imports in tons are much larger than exports in tons. It is also different to India, where exports and imports in tons are more or less balanced. In South America there are chronic Physical Trade Deficits, which means that a larger volume of materials is exported than is imported. In recent years, this has been accompanied by a deficit in the monetary trade balance, leading to greater external debts or outflows of currency reserves. If the deficit in the monetary trade balances continues or is aggravated further, there might be a trend to compensate this by increasing the 
deficit in the PTB and concomitantly incurring 'democratic deficits' at the local level, as protests are politically repressed.

In contrast, India has a low level of material use per capita/year and may be doubling its GDP in ten or fifteen years. As the economy grows the material flows will also increase, although at different rates. In material terms, India will be like four Latin Americas (because of its larger population and increased material use), and this is to be fitted into a much smaller space. Biomass will increase much less than metal ores, building materials, and fossil fuels, which will grow faster than the rate of economic growth. How the pattern of external trade in India will develop is not yet obvious. Probably it will become a relatively large net importer in material terms. Across India, the pattern of internal colonialism is likely to increase. There is already large scale expropriation and evictions of people giving rise to a strong "environmentalism of the poor." The thesis of the environmentalism of the poor applies also to Latin America, where it has been used since 1991. It does not assert that poor people or even indigenous peoples feel, think, and behave like environmentalists. Rather, the thesis is that in the many historical and contemporary conflicts over resource extraction and waste disposal, the poor often advocate the protection of nature from the interests of business and the state. This behaviour is consistent with their own interests and their values. The environmentalism of the poor builds on the premise that the struggles for human rights and for the environment are inseparable.

Local environmental conflicts arise because of rapid changes in the structure of the social metabolism, for instance new types of production and uses of biomass (e.g., eucalyptus plantations, soybean monocultures), a new wave of open cast metal mining or gas fracking, or new plans for waste dumps or incinerators. While some types of materials (sand and gravel, for instance) do not tend to generate conflicts in some places with low population density, they can become very conflictive in other countries, as in India, because of their effects on rivers and beaches. What was a permanent 'fund' provided by nature (a seasonal pattern of flows of water in the rivers, spaces for cultivation in the dry season) is treated as a 'flow' of materials for the building industry.

Questions that we aim to answer as we increase the number of cases in the EJAtlas include the following: What is the rate of 'success' of environmental justice in such conflicts? Does population density help to explain the incidence of socio-environmental conflicts? Is local scarcity of water a relevant factor? How does the presence of indigenous populations affect the rate of successful outcomes? We have presented a few provisional results from the EJAtlas, focusing on some of the research questions of a new "comparative, statistical political ecology." Together with the well-meaning and rather useless efforts of the eco-efficiency and ecological modernization movements, and sometimes in alliance with conservationism, the global environmental justice movement can be considered a very relevant actor in the struggle for sustainability.

As regards environmental conflicts, in South America the economic crisis of 2015 - partly due to overinvestment in the extractive industries and the rapidly declining terms of trade - may reinforce 'postextractivist' agendas. The crisis will at least increase support for many local movements of resistance against extractive projects and transport investments, which are struggling to safeguard livelihoods and environmental sustainability. In South America there is a new pride in its own 'post-extractivist', post-development ideologies, such as Buen Vivir or Sumak Kawsay (Acosta, 2013). In India the panorama is different, though not because of lack of competent EJOs defending the environment and poor peoples' livelihoods. The country is on an irresistible path of rapid economic growth. Nevertheless there are many local resistance movements and alternatives, as well as new conceptions (in parallel to Buen Vivir and 'post-extractivism' in South America, building on India's own roots, under names such as Radical Ecological Democracy and ecological swaraj (Shrivastava and Kothari, 2012). One transcontinental confluence of ideas is the recent article by Kothari, Demaria and Acosta (2014).

\section{References}

Acosta, A. 2013. Extractivism and neoextractivism: two sides of the same curse. In Lang, M. and D. Mokrani (eds.). Beyond development: alternative visions from Latin America. Quito and Amsterdam: Rosa Luxemburg Foundation and Transnational Institute. Pp. 61-86.

Agarwal, B. 1992. The gender and environment debate: lessons from India. Feminist Studies 18 (1): $119-158$. 
Bandyopadhyay, J. and V. Shiva. 1988. Political economy of ecology movements. Economic and Political Weekly 23(24): 1223-1232.

Bunker, S. 2007. The poverty of resource extraction. In Hornborg A., J. McNeill and J. Martínez-Alier (eds.) Rethinking environmental history: world-system history and global environmental change. Lanham: AltaMira.

Bullard, R. 1990. Dumping in Dixie: race, class, and environmental quality. Boulder, CO: Westview Press.

Carrere, R. and L. Lohmann. 1996. Pulping the South: industrial tree plantations and the world paper economy. Zed: London.

Kothari, A., F. Demaria and A. Acosta. 2014. Buen vivir, degrowth and ecological swaraj: alternatives to sustainable development and the green economy. Development 57: 362-375.

Dorninger C. and N. Eisenmenger. 2016. South America's biophysical involvement in international trade: the physical trade balances of Argentina, Bolivia, and Brazil in the light of ecologically unequal exchange. Journal of Political Ecology 23: 394-409.

Fischer-Kowalski, M. 1997. Society's metabolism: on the childhood and adolescence of a rising conceptual star. InRedclift M. and G. Woodgate. (eds.) The international handbook of environmental sociology. Cheltenham: Edward Elgar. Pp. 119-137.

Fischer-Kowalski, M. and H. Haberl. 2015. Social metabolism: a metric for biophysical growth and degrowth. In J. Martinez-Alier and R. Muradian. Handbook of ecological economics. Cheltenham: Edward Elgar. Pp. 100-138.

Gerber, J.-F. 2011. Conflicts over industrial tree plantations in the South: who, how and why? Global Environmental Change 21(1):165-176.

Gonzalez-Martinez, A.C. and H. Schandl. 2008. The biophysical perspective of a middle income economy: material flows in Mexico. Ecological Economics 68(1-2): 317-27.

Gudynas, E. 2009. Diez tesis urgentes sobre el nuevo extractivismo. Contextos y demandas bajo el Progresismo. CLAES. Montevideo.

Guha, R. and J. Martinez-Alier. 1997. Varieties of environmentalism: essays North and South. Delhi: Oxford University Press.

Guha, R. and J. Martinez-Alier, 1999. Political ecology, the environmentalism of the poor, and the global movement for environmental justice. Kurswechsel 3:27-40.

Haas, W., F. Krausmann, D. Wiedenkofer and M. Heinz. 2015. How circular is the global economy? An assessment of material flows, waste production, and recycling in the European Union and the world in 2005. Journal of Industrial Ecology 19(5): 765-777.

Haberl, H., K.H. Erb, F. Krausmann, V. Gaube, A. Bondeau, C. Plutzar, S. Gingrich, W. Lucht and M. FischerKowalski. 2007. Quantifying and mapping the Human Appropriation of Net Primary Production in Earth's terrestrial ecosystems. Proceedings of the National Academy of Sciences 104(31):1294212947.

Hornborg, A. 1998. Towards an ecological theory of unequal exchange: articulating world system theory and ecological economics. Ecological Economics 25: 127 - 136.

Hornborg, A. 2009. Zero-sum world: challenges in conceptualizing environmental load displacement and ecologically unequal exchange in the world-system. International Journal of Comparative Sociology 50(3-4):237-262.

Hornborg, A. 2006. Footprints in the cotton fields: the industrial revolution as time-space appropriation and environmental load displacement. Ecological Economics 59(1):74-81.

Kapp, K.W. 1950. The social costs of private enterprise. Cambridge: Harvard University Press.

Martinez-Alier, J. 2002. The environmentalism of the poor: a study of ecological conflicts and valuation. Cheltenham: Edward Elgar. Ch.1, 2.

Martinez-Alier, J. 2009. Social metabolism, ecological distribution conflicts, and languages of valuation. Capitalism Nature Socialism 20(1): 58-87. 
Martinez-Alier, J., H. Healy, L. Temper, M. Walter, B. Rodriguez-Labajos, J.F. Gerber and M. Conde 2011. Between science and activism: learning and teaching ecological economics with Environmental Justice Organisations. Local Environment 16(1): 17-36. draft

Martinez-Alier, J. and M. O'Connor. 1996. Ecological and economic distribution conflicts. In Costanza, R. and O. Segura. (eds.). Getting down to earth: practical applications of ecological economics. Washington: Island Press.

Martinez-Alier, J., L. Temper, D. Del Bene and A. Scheidel. 2016. Is there a global environmental justice movement? The Journal of Peasant Studies 43(3): 731-755.

Martinez-Alier, J., L. Temper and F. Demaria. 2014. Social metabolism and environmental conflicts in India. Indialogs 1(1): 51-83.

Martinez-Alier, J., I. Anguelovski, P. Bond, D. Del Bene, F. Demaria, J.F. Gerber, L. Greyl, W. Haas, H. Healy, V. Marín-Burgos, G. Ojo, M.F. Porto, L. Rijnhout, B. Rodríguez-Labajos, J. Spangenberg, L. Temper, R. Warlenius and I. Yánez. 2014. Between activism and science: grassroots concepts for sustainability coined by environmental justice organizations. Journal of Political Ecology 21: 19-60.

Mc Cully, P. 1996. Silenced rivers: the ecology and politics of large dams. London: Zed.

Moore, J.W. 2000. Sugar and the expansion of the early modern world-economy: commodity frontiers, ecological transformation, and industrialization. Review (Fernand Braudel Center). 23(3): 409-433.

Muradian, R. and J. Martinez-Alier. 2001. Trade and the environment: from a 'Southern' perspective. Ecological Economics 36: 281-297.

Muradian, R., M. Walter and J. Martinez-Alier. 2012. Hegemonic transitions and global shifts in social metabolism: implications for resource-rich countries. Global Environmental Change 22(3): 559-567. Researchgate

Narain, S. 2011. How to be or not to be Year of Environment. Business Standard. January 10.

Padel, F. and S. Das. 2010. Out of this earth: East India adivasis and the aluminium cartel. Hyderabad: Orient Black Swan.

Pérez Manrique, P.L., J. Brun, A.C. González-Martínez, M. Walter and J. Martínez-Alier. 2013. The biophysical performance of Argentina (1970-2009). Journal of Industrial Ecology 17(4):590-604. draft

Pérez-Rincón, M.A. 2006 Colombian international trade from a physical perspective: towards an ecological "Prebisch thesis." Ecological Economics 59(4): 519-529.

Pérez-Rincón, M.A. 2014. Conflictos ambientales en Colombia. In Garay, L.J. (ed.) Minería en Colombia: control público, memoria y justicia socio-ecológica, movimientos sociales y posconflicto. Bogota: Contraloría General de la República de Colombia. Pp. 253-326.

Pope Francis 2015. Care for our common home. Encyclical Letter Laudato Si' of the Holy Father Francis. The Vatican.

Raikes, P., M.F. Jensen, and S. Ponte. 2000. Global commodity chain analysis and the french filière approach: comparison and critique. Economy and Society 29(3):390-417. draft

Robbins, Paul. 2004. Political ecology: a critical introduction. Oxford: Blackwell.

Rodriguez-Labajos, B. and J. Martinez-Alier. 2015. The political ecology of water conflicts. WIREs Water 2: 537-558. Academia

Russi, D., A.C. Gonzalez, J.C. Silva-Macher, S. Giljum, J. Martinez-Alier and M.C. Vallejo. 2008. Material flows in Latin America: a comparative analysis of Chile, Ecuador, Mexico, and Peru, 1980-2000. Journal of Industrial Ecology 12(5-6): 704-720.

Samaniego, P., M.C. Vallejo and J. Martinez-Alier. 2017. Commercial and biophysical deficits in South America, 1990-2013. forthcoming in Ecological Economics.

Shrivastava, A. and Kothari, A. 2012. Churning the Earth. The making of global India, Penguin Books, Delhi.

Singh, S.J., F. Krausmann, S. Gingrich, H. Haberl, K.H. Erb, P. Lanz and L. Temper. 2012. India's biophysical economy, 1961-2008: sustainability in a national and global context. Ecological Economics 76: 60-69.

Singh, A.A., M. Mahongnao, F. Demaria and V.V. Krishna. 2014. Illegal sand mining conflicts in India. 
EJOLT Factsheet No. 010.

Svampa, M. 2015. Commodities consensus: neoextractivism and enclosure of the commons in Latin America. South Atlantic Quarterly 114(1): 65-82.

Temper, L., Del Bene, D., Martinez-Alier, J. 2015. Mapping the frontiers and front lines of global environmental justice: the EJAtlas. Journal of Political Ecology 22: 255-278.

Temper L. 2016. Who gets the HANPP (Human Appropriation of Net Primary Production)? Biomass distribution and the 'sugar economy' in the Tana Delta, Kenya. Journal of Political Ecology 23: 410433.

Temper, L. and J. Martinez-Alier. 2013. The god of the mountain and Godavarman: Net Present Value, indigenous territorial rights and sacredness in a bauxite mining conflict in India. Ecological Economics 96: 79-87. Researchgate

Vallejo, M.C., M.A. Pérez-Rincón and J. Martinez-Alier. 2011. Metabolic profile of the Colombian economy from 1970 to 2007. Journal of Industrial Ecology 15(2): 245-267.

West, J., and H. Schandl. 2013. Material use and material efficiency in Latin America and the Caribbean. Ecological Economics 94:19-27. draft 